\title{
A NEW TETRANUCLEAR DISTORTED OPEN-CUBANE COPPER(II) SCHIFF BASE COMPLEX: STRUCTURAL, SPECTRAL AND MAGNETIC CHARACTERIZATIONS
}

\author{
E. Gungor ${ }^{1}$, H. Kara ${ }^{1,2}$ \\ ${ }^{1}$ Department of Physics, Faculty of Science and Art, Balikesir University, Balikesir, Turkey \\ E-mail: egungor@balikesir.edu.tr \\ ${ }^{2}$ Department of Physics, Faculty of Science, Mugla Sitki Koçman University, Mugla, Turkey
}

Received June, 17, 2014

\begin{abstract}
A new tetranuclear complex $\left[\mathrm{Cu}_{4}(\mathrm{~L})_{4}\right](\mathbf{1})\left(\mathrm{H}_{2} \mathrm{~L}=\mathrm{N}\right.$-(2-hydroxyethyl)-3-metoxysalicylaldimine) has been synthesized and characterized by crystal structure analysis and magnetic susceptibility. Single-crystal X-ray diffraction studies reveal that complex 1 contains three independent $\mathrm{Cu}_{4} \mathrm{O}_{4}$ open-cubane cores of $4+2$ type (four short and two long $\mathrm{Cu} \cdots \mathrm{Cu}$ distances), where the copper(II) centers are linked by alkoxo-bridges. Each copper(II) ion have a distorted squarepyramidal geometry. Variable-temperature magnetic susceptibility measurements on the tetranuclear complex 1 in the range $2-300 \mathrm{~K}$ indicate dominant antiferromagnetic coupling $(J=$ $=-108.46$ ) between copper(II) centers.
\end{abstract}

DOI: $10.15372 / J S C 20150829$

K e y w o r d s: Schiff base, tetranuclear copper(II) complex, antiferromagnetic interaction.

\section{INTRODUCTION}

There has been continuous interest in high-nuclearity transition-metal complexes because their importance in the field of molecular magnetism [1 ] and bioinorganic chemistry [2 ]. Especially, $\mathrm{M}_{4} \mathrm{O}_{4}$ cubane type complexes (where $\mathrm{M}=\mathrm{Cu}, \mathrm{Ni}, \mathrm{Co}, \mathrm{Fe}, \mathrm{Mn}$ ) have been extensively studied since their application as single molecule magnets (SMMs) [3-5] and their possible utility in modeling of the active sites of metalloenzymes in biological systems [6,7]. Among them, $\mathrm{Cu}_{4} \mathrm{O}_{4}$ cubane type complexes are studied enthusiastically due to their intermediate size between the simplest binuclear complexes and bulk materials, which may develop completely new magnetic properties, thus providing good models of nanometer sized magnetic particles [8].

Polydentate Schiff base hydroxyl-rich ligands as well as hydroxyl-rich ligands form various kinds of polynuclear complexes having diverse structural, biological and magnetic properties due to the propensity of the terminal oxygens to act as bridging groups [9-11]. The steric and electronic factors of the Schiff base can be tuned systematically by introducing suitable substituents to bring about subtle structural variations that are extremely useful for deducing a relationship between magnetic coupling and structural features [12 ]. Several theoretical analyses have been carried out to clarify the structures and magnetic properties of the cubane type tetranuclear copper(II) complexes, and different magnetic behaviour ranging from ferro- to antiferromagnetic interactions has been found in these systems $[13,14]$.

Recently our research group and others have reported the structural and magnetic characterization of polynuclear copper(II) complexes with Schiff base ligands [ 15-26]. In view of the importance of copper(II) compounds and our interest in the magnetic properties of transition metal complexes, we report here the synthesis, crystal structure and magnetic properties of a new tetranuclear copper(II)

(C) Gungor E., Kara H., 2015 
complex containing three independent distorted open-cubane core. It is interesting to note that although some structural and magnetic analyses of cubane copper(II) complexes have been reported [21-26], complex 1 represents the first example of an exchange coupled open-cubane copper(II) complex with three independent $\mathrm{Cu}_{4} \mathrm{O}_{4}$ cores.

\section{EXPERIMENTAL}

Materials and physical measurements. All chemical reagents and solvents were purchased from Merck or Aldrich and used without further purification. Elemental $(\mathrm{C}, \mathrm{H}, \mathrm{N})$ analyses were carried out by standard methods with a LECO, CHNS-932 analyzer. FT-IR spectra were measured with a PerkinElmer Model Bx 1600 instrument with the samples as $\mathrm{KBr}$ pellets in the $4000-400 \mathrm{~cm}^{-1}$ range. The temperature dependence of the magnetic susceptibility of polycrystalline samples was measured between $2 \mathrm{~K}$ and $300 \mathrm{~K}$ at a field of $1.0 \mathrm{~T}$ using a Quantum Design model MPMS computer-controlled SQUID magnetometer. The effective magnetic moments were calculated from the equation $\mu_{\text {eff }}=2.828\left(\chi_{m} T\right)^{1 / 2}[1]$, where $\chi_{m}$, the molar magnetic susceptibility, was set equal to $M_{m} / \mathrm{H}$. The synthetic route of the ligand and complexes are depicted in Scheme 1.

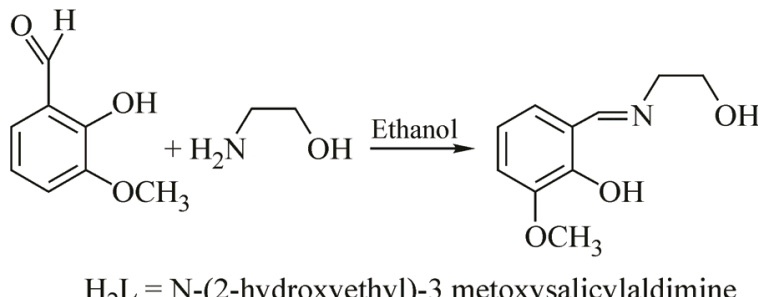

Scheme 1. The ligand $\mathbf{H}_{\mathbf{2}} \mathbf{L}$ evaluated in this study

Synthesis of complex 1. The tridentate Schiff base ligand, $\mathbf{H}_{2} \mathbf{L}$, was prepared by reaction of ethanolamine $(1 \mathrm{mmol})$ with 2-hydroxy-3-methoxybenzdehyde $(1 \mathrm{mmol})$ in hot ethanol $\left(60 \mathrm{~cm}^{3}\right)$ according to the method reported previously [27]. The solution obtained was stirred at $65{ }^{\circ} \mathrm{C}$ for $10 \mathrm{~min}$. The yellow compound precipitated from the solution on cooling. Complex $\mathbf{1}$ was prepared by addition of copper(II) acetate monohydrate $(1 \mathrm{mmol}, 0.199 \mathrm{~g})$ in $20 \mathrm{~cm}^{3}$ of hot methanol to the ligand $(1 \mathrm{mmol}$, $0.195 \mathrm{~g})$ in $30 \mathrm{~cm}^{3}$ of hot ethanol. To the resulting solutions $1 \mathrm{mmol}$ of triethylamine $\left(\mathrm{Et}_{3} \mathrm{~N}\right)$ was then added. This solution has been warmed to $78{ }^{\circ} \mathrm{C}$ and stirred for $15 \mathrm{~min}$, filtered rapidly and the filtrate allowed to stand at room temperature. After several weeks green crystals of the title compound suitable for X-ray analysis were isolated.

$\mathbf{H}_{2}$ L. Brown crystals, yield 75 \%. Calcd. (\%): C 54.15, H 5.05, N 7.02. Found (\%): C 54.11, H 5.15, N 7.10. IR (KBr) cm $\mathrm{cm}^{-1}$ : 3183, 2953, 2894, 2363, 2155, 1640, 1522, 1439, 1361, 1228, 1202 , 1116, 1081, 968, 840, 699, 645.

Complex 1. Green crystals, yield $70 \%$. For $\mathrm{C}_{40} \mathrm{H}_{48} \mathrm{~N}_{4} \mathrm{O}_{12} \mathrm{Cu}_{4}$ : Calcd. (\%): C 46.59, H 4.69, $\mathrm{N}$ 5.43. For $\mathrm{C}_{40} \mathrm{H}_{48} \mathrm{~N}_{4} \mathrm{O}_{12} \mathrm{Cu}_{4} \cdot 2 \mathrm{H}_{2} \mathrm{O}$ Calcd. (\%): C 45.02, H 4.92, N 5.25. Found (\%): $\mathrm{C} 45.63, \mathrm{H} 4.60$, N 5.08. IR (KBr) cm ${ }^{-1}: 3389,3266,3428,3053,2923,2828,2360,1648,1597,1244,1222,1160$, $1098,978,852,738,622,578,551,481$.

X-ray structure determinations. The diffraction measurements were collected on a Bruker Apex II kappa CCD diffractometer using graphite monochromated $\operatorname{Mo} K_{\alpha}$ radiation $(\lambda=0.71073 \AA)$ at $100 \mathrm{~K}$ for 1 . The intensity data were integrated using the APEXII program [28 ]. Absorption corrections were applied based on equivalent reflections with SADABS [29]. The structures were solved by direct methods and refined by full-matrix least-squares treatment against $F^{2}$ using SHELXL [30 ]. All non-hydrogen atoms were assigned anisotropic displacement parameters and refined without positional constraints. Hydrogen atoms were included in idealized positions with isotropic displacement parameters constrained to 1.5 times the $U_{\text {eq }}$ of their attached carbon atoms for methyl hydrogens, and 1.2 times the $U_{\text {eq }}$ of their attached carbon atoms for the rest. The water molecules in the crystal lattice appear to be highly disordered, and it was difficult to model reliably their positions and distribution. 
Therefore, the SQUEEZE function of PLATON [31] was used to eliminate the contribution of the electron density in the solvent region from the intensity data, and the solvent free model was employed for the final refinement. The solvent water molecules and their hydrogen atoms were not included in the total atomic formula and they are not included in the list of atoms. Chemical analysis for this compound suggests the occurrence of one or two lattice water molecules per tetranuclear unit.

Powder X-ray diffraction measurements were performed using $\mathrm{Cu} K_{\alpha}$ radiation $(\lambda=1.5418 \AA)$ on a Bruker-AXS D8-Advance diffractometer equipped with a secondary monochromator. The data were collected in the range $5<2 \theta<50^{\circ}$ in $\theta-\theta$ mode with a step time of ns $(5 \mathrm{~s}<n<10 \mathrm{~s})$ and step width of $0.03^{\circ}$. The powder patterns for the bulk microcrystalline sample of 1 were consistent with the exclusive presence of the phase identified in the single crystal experiment.

\section{RESULTS AND DISCUSSION}

Crystal structure. The crystallographic data, conditions used for the intensity data collection and some features of the structure refinement are listed in Table 1. Selected angles for the complex are given in Table 2. A perspective ORTEP view with the atom-labeling scheme is presented in Fig. 1.

$\mathrm{T}$ a b 1 e 1

Crystal data and structure refinement for $\mathbf{1}$

\begin{tabular}{l|}
\hline \multicolumn{1}{c|}{ Parameter } \\
\hline Chemical formula \\
Formula weight \\
Temperature, $\mathrm{K}$ \\
Crystal system; Space group \\
Unit cell dimensions $a, b, c, \AA ; \beta$, deg. \\
$V, \AA^{3} ; Z$ \\
$\rho_{\text {calc }}, \mathrm{g} / \mathrm{cm}^{3}$ \\
$\mu, \mathrm{mm}^{-1}$ \\
Reflections collected / independent \\
Refinement method \\
Data / parameters \\
Goodness-of-fit on $F^{2}$ \\
$R$ indices $[I>2 \sigma(I)]$
\end{tabular}

1

$\mathrm{C}_{120} \mathrm{H}_{132} \mathrm{Cu}_{12} \mathrm{~N}_{12} \mathrm{O}_{36}$ 3081.99

$100(2)$

Monoclinic; $P 2_{1} / c$

$24.2532(8), 12.0878(4), 49.1750(15) ; 116.552(2)$

$12896.0(8) ; 4$

1.587

2.017

$217671 / 29681$

Full-matrix least-squares on $F^{2}$ $29681 / 1762$

1.23

$R_{1}=0.1399, w R_{2}=0.2872$

$\mathrm{Table} 2$

Some selected angles (deg.) for $\mathbf{1}$

\begin{tabular}{l|r||r|r|||c|c}
\hline \multicolumn{3}{c||}{ Cubane $\mathrm{A}$} & \multicolumn{3}{c||}{ Cubane $\mathrm{B}$} \\
\hline $\mathrm{Cu} 1-\mathrm{O} 1-\mathrm{Cu} 3$ & $104.3(3)$ & $\mathrm{Cu} 5-\mathrm{O} 14-\mathrm{Cu} 6$ & $112.200(4)$ & $\mathrm{Cu} 9-\mathrm{O} 33-\mathrm{Cu} 10$ & $109.600(4)$ \\
$\mathrm{Cu} 1-\mathrm{O} 7-\mathrm{Cu} 4$ & $104.9(4)$ & $\mathrm{Cu} 5-\mathrm{O} 20-\mathrm{Cu} 7$ & $106.500(4)$ & $\mathrm{Cu} 9-\mathrm{O} 28-\mathrm{Cu} 11$ & $106.800(4)$ \\
$\mathrm{Cu} 1-\mathrm{O} 1-\mathrm{Cu} 2$ & $102.3(4)$ & $\mathrm{Cu} 5-\mathrm{O} 23-\mathrm{Cu} 8$ & $105.8(4)$ & $\mathrm{Cu} 9-\mathrm{O} 28-\mathrm{Cu} 12$ & $99.600(3)$ \\
$\mathrm{Cu} 1-\mathrm{O} 4-\mathrm{Cu} 2$ & $95.9(3)$ & $\mathrm{Cu} 5-\mathrm{O} 14-\mathrm{Cu} 8$ & $94.600(3)$ & $\mathrm{Cu} 9-\mathrm{O} 39-\mathrm{Cu} 12$ & $97.700(3)$ \\
$\mathrm{Cu} 1-\mathrm{O} 7-\mathrm{Cu} 3$ & $91.5(3)$ & $\mathrm{Cu} 5-\mathrm{O} 23-\mathrm{Cu} 7$ & $90.300(3)$ & $\mathrm{Cu} 9-\mathrm{O} 39-\mathrm{Cu} 10$ & $91.8(3)$ \\
$\mathrm{Cu} 1-\mathrm{O} 4-\mathrm{Cu} 4$ & $90.3(3)$ & $\mathrm{Cu} 5-\mathrm{O} 20-\mathrm{Cu} 6$ & $87.600(3)$ & $\mathrm{Cu} 9-\mathrm{O} 33-\mathrm{Cu} 11$ & $89.900(4)$ \\
$\mathrm{Cu} 2-\mathrm{O} 4-\mathrm{Cu} 4$ & $104.4(4)$ & $\mathrm{Cu} 6-\mathrm{O} 17-\mathrm{Cu} 7$ & $101.900(3)$ & $\mathrm{Cu} 10-\mathrm{O} 39-\mathrm{Cu} 12$ & $106.100(4)$ \\
$\mathrm{Cu} 2-\mathrm{O} 10-\mathrm{Cu} 3$ & $99.0(3)$ & $\mathrm{Cu} 6-\mathrm{O} 20-\mathrm{Cu} 7$ & $93.900(3)$ & $\mathrm{Cu} 10-\mathrm{O} 33-\mathrm{Cu} 11$ & $97.300(4)$ \\
$\mathrm{Cu} 2-\mathrm{O} 1-\mathrm{Cu} 3$ & $93.7(3)$ & $\mathrm{Cu} 6-\mathrm{O} 17-\mathrm{Cu} 8$ & $90.300(3)$ & $\mathrm{Cu} 10-\mathrm{O} 36-\mathrm{Cu} 11$ & $95.100(3)$ \\
$\mathrm{Cu} 2-\mathrm{O} 10-\mathrm{Cu} 4$ & $88.2(3)$ & $\mathrm{Cu} 6-\mathrm{O} 14-\mathrm{Cu} 8$ & $89.900(3)$ & $\mathrm{Cu} 10-\mathrm{O} 36-\mathrm{Cu} 12$ & $88.800(3)$ \\
$\mathrm{Cu} 3-\mathrm{O} 10-\mathrm{Cu} 4$ & $101.2(3)$ & $\mathrm{Cu} 7-\mathrm{O} 23-\mathrm{Cu} 8$ & $105.900(5)$ & $\mathrm{Cu} 11-\mathrm{O} 28-\mathrm{Cu} 12$ & $92.000(4)$ \\
$\mathrm{Cu} 3-\mathrm{O} 7-\mathrm{Cu} 4$ & $97.7(3)$ & $\mathrm{Cu} 7-\mathrm{O} 17-\mathrm{Cu} 8$ & $90.300(3)$ & $\mathrm{Cu} 11-\mathrm{O} 36-\mathrm{Cu} 12$ & $88.800(3)$
\end{tabular}




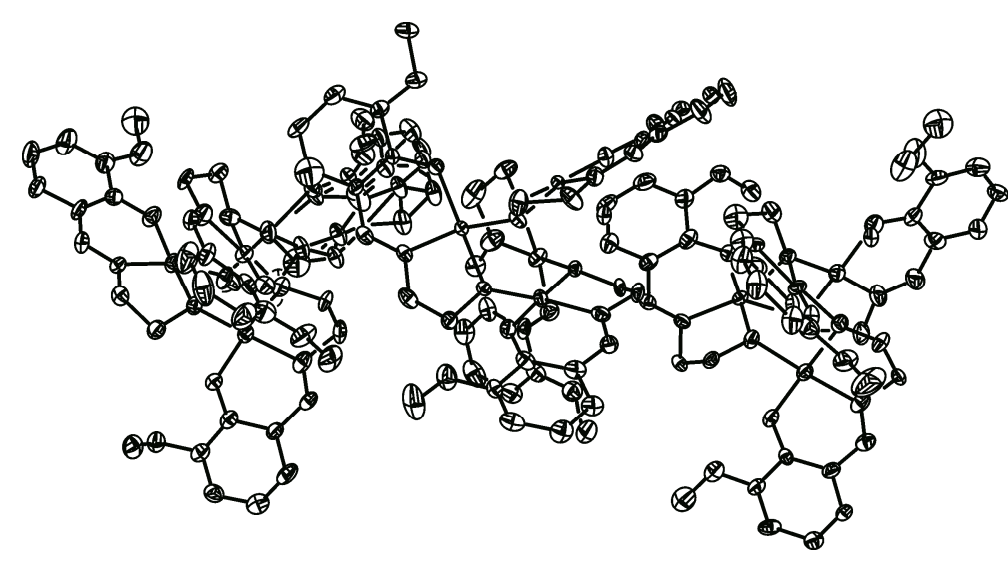

Fig. 1. ORTEP drawing of complex $\mathbf{1}$.

The hydrogen atoms were omitted for clarity

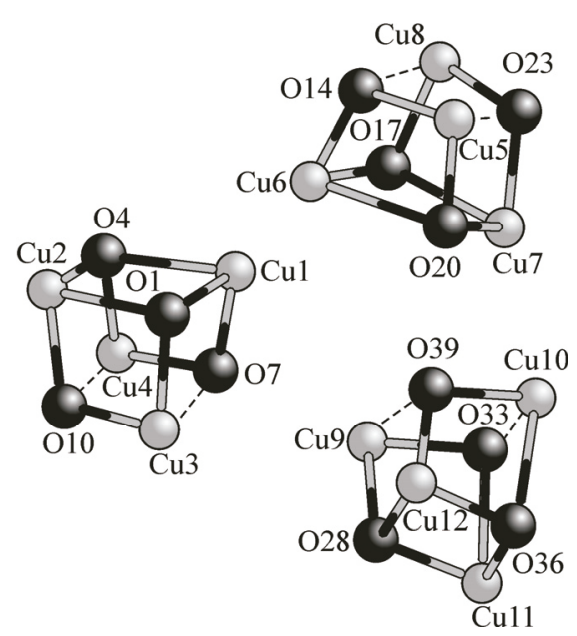

Fig. 2. A view of three independent open-cubane $\mathrm{Cu}_{4} \mathrm{O}_{4}$ core in the asymmetric unit of 1

Complex 1 crystallizes in the monoclinic space group $P 2_{1} / c$. Its crystal structure is different from other cubane $\mathrm{Cu}_{4} \mathrm{O}_{4}$ core structures in having three independent alkoxo-bridged open-cubane $\mathrm{Cu}_{4} \mathrm{O}_{4}$ cores in the asymmetric unit (Fig. 2). Three independent cores have different geometries. All copper(II) centers are pentacoordinate with one phenoxo oxygen, one amino nitrogen and three deprotonated bridging alkoxo-oxygen atoms. For the coordination polyhedron of the metal atom, the distortion of the coordination environment from TBP to SP can be evaluated by the Addison distortion index, $\tau$, defined as $\tau=(\alpha-\beta) / 60$, where $\alpha$ and $\beta$ are the two largest coordination angles. The value of 0 for perfect SP and 1 for ideal TBP $[32,33]$. The structural distortion indices of the copper atoms are $\tau_{\mathrm{Cu} 1}=0.012$, $\tau_{\mathrm{Cu} 2}=0.078, \tau_{\mathrm{Cu} 3}=0.018, \tau_{\mathrm{Cu} 4}=0.097, \tau_{\mathrm{Cu} 5}=0.081, \tau_{\mathrm{Cu} 6}=0.088, \tau_{\mathrm{Cu} 7}=0.058, \tau_{\mathrm{Cu} 8}=0.057, \tau_{\mathrm{Cu} 9}=$ $=0.166, \tau_{\mathrm{Cu} 10}=0.019, \tau_{\mathrm{Cu} 11}=0.052$ and $\tau_{\mathrm{Cu} 12}=0.035$. Each copper(II) atom has a slightly distorted square pyramidal environment. The copper atoms deviate from the $\mathrm{NO}_{3}$ basal planes by $0.082 \AA$, $0.336 \AA, 0.067 \AA, 0.111 \AA, 0.093 \AA, 0.105 \AA, 0.145 \AA, 0.075 \AA, 0.060 \AA, 0.055 \AA, 0.037 \AA$, and $0.116 \AA$, respectively. The basal $\mathrm{Cu}-\mathrm{O}$ bond distances are in the range $1.875(9)-2.085(8) \AA$, while the axial bond distances range from $2.085(8) \AA$ to $2.656(8) \AA$ owing to the Jahn-Teller effect which is typical for copper(II) $d^{9}$ system. The basal $\mathrm{Cu}-\mathrm{N}$ bond distances and $\mathrm{Cu}-\mathrm{O}_{\text {alkoxo }}-\mathrm{Cu}$ bridging bond angles for $\mathbf{1}$ are $1.906(11)-2.060(15) \AA$ and $87.60(3)-112.20(4)^{\circ}$. The $\mathrm{Cu} \cdots \mathrm{Cu}$ distances on different cubic faces are also different and are in the range of $3.051 \AA$ to $3.401 \AA$. These geometrical features of copper centers in $\mathbf{1}$ are quite comparable to those of the similar tetranuclear complexes reported in the literature $[21-26]$.

FTIR spectroscopy. The IR spectrum of $\mathbf{1}$ was analyzed was compared with free $\mathbf{H}_{2} \mathbf{L}$ in the region $4000-400 \mathrm{~cm}^{-1}$. The IR spectrum of $\mathbf{H}_{2} \mathbf{L}$ shows a broad band in a region $3266-3428 \mathrm{~cm}^{-1}$ due to $\mathrm{O}-\mathrm{H}$ stretching, which disappears in the complex, indicating the deprotonation of the Schiff base upon complexation. Several weak peaks in the range $2828-3053 \mathrm{~cm}^{-1}$ are likely due to the aromatic and aliphatic $\mathrm{C}-\mathrm{H}$ stretches. The strong absorption band at $1648 \mathrm{~cm}^{-1}$ can be assigned to the $\mathrm{C}=\mathrm{N}$ stretching frequency of the coordinated Schiff base ligand. The shift of this band compared to that of the free Schiff base ligand $\left(1640 \mathrm{~cm}^{-1}\right)$ indicates the coordination of the imine nitrogen atom to the metal center. The phenolic $\mathrm{C}-\mathrm{O}$ in the free ligand exhibits a strong band at $1278-1240 \mathrm{~cm}^{-1}$, whereas in the complex this band is observed in the lower frequency region at $1222-1160 \mathrm{~cm}^{-1}$, providing evidence for coordination to the metal ions through the deprotonated phenolic oxygen atoms [34 ]. The IR spectrum of complex 1 confirms the presence of water molecules. The broad band at $3389 \mathrm{~cm}^{-1}$ is attributable to $(\mathrm{O}-\mathrm{H})$ vibrations. Generally, the $\mathrm{O}-\mathrm{H}$ stretching vibration for water appears above $3400 \mathrm{~cm}^{-1}$ [35]. Ligand coordination to the metal center is substantiated by prominent bands appearing at $551 \mathrm{~cm}^{-1}$ and $481 \mathrm{~cm}^{-1}$ which can be attributed to $v(\mathrm{Cu}-\mathrm{N})$ and $v(\mathrm{Cu}-\mathrm{O})$, respectively. 


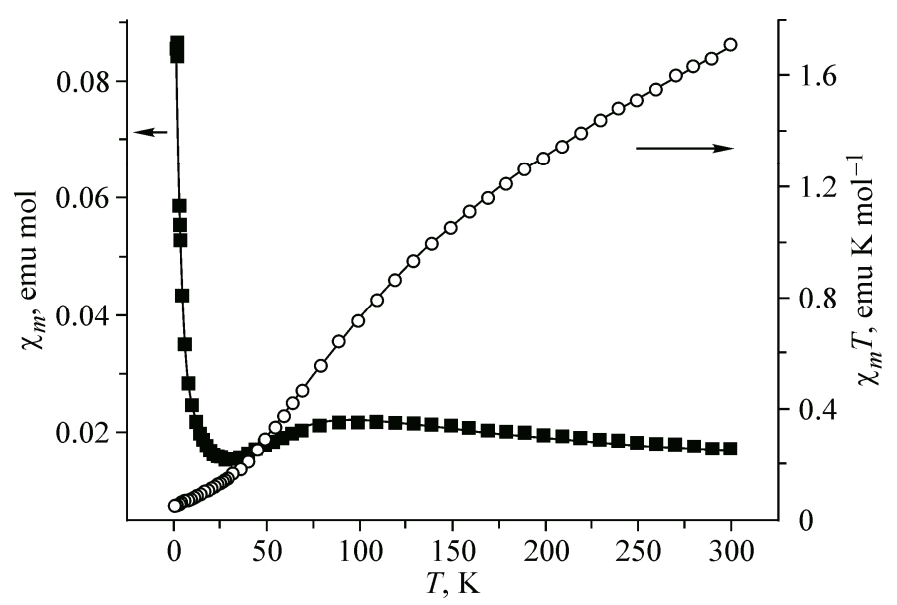

Fig. 3. Temperature dependence of $\chi_{m}$ and $\chi_{m} T$ for 1 . The solid red line represents the fit obtained by the Curie-Weiss law

Magnetic properties. The temperature dependence of $\chi_{M} T\left(\chi_{M}\right.$ is the molar magnetic susceptibility per $\mathrm{Cu}_{4}$ unit) for $\mathbf{1}$ in the range $300-2 \mathrm{~K}$ and at an applied field of 1000 Oe is shown in Fig. 3. The $\chi_{\mathrm{M}} T$ value at room temperature $\left(1.71 \mathrm{~cm}^{3} \cdot \mathrm{mol}^{-1} \cdot \mathrm{K}\right)$ is slightly higher than expected for four uncoupled $\mathrm{Cu}^{2+}$ ions $(S=1 / 2)$ with $g=2.0$ $\left(1.50 \mathrm{~cm}^{3} \cdot \mathrm{mol}^{-1} \cdot \mathrm{K}\right)$. When the temperature is lowered, the curve shows a continuous decay tending to a plateau at temperatures below $30 \mathrm{~K}$. The value at $1.9 \mathrm{~K}$ is $0.053 \mathrm{~cm}^{3} \cdot \mathrm{mol}^{-1} \cdot \mathrm{K}$. This behavior is indicative of a dominant antiferromagnetic coupling that leads to a $S=0$ spin ground state together with some paramagnetic impurities that make the $\chi_{\mathrm{M}} T$ vs. $T$ curve to deviate from 0 at low temperatures. As has been described in the structural part, the $\mathrm{Cu}(\mathrm{II})$ ions build three different cubane-like tetramers, $\mathbf{A}, \mathbf{B}$ and $\mathbf{C}$ (Scheme 2). Although three cubanes have the same pattern $(4+2$ class), the $\mathrm{Cu} \cdots \mathrm{Cu}$ and $\mathrm{Cu}-\mathrm{O}$ distances and the $\mathrm{Cu}-\mathrm{O}-\mathrm{Cu}$ angles have significant differences cubanes $\mathbf{A}, \mathbf{B}$ and $\mathbf{C}$ (Table 2). The $\mathrm{Cu} \cdots \mathrm{Cu}$ distances range from $3.051 \AA$ to $3.311 \AA$ for cubane A, $3.113 \AA$ to $3.401 \AA$ for cubane $\mathbf{B}$, and $3.118 \AA$ to $3.371 \AA$ for cubane C. Therefore, nine different magnetic exchange-pathways for $\mathbf{A}, \mathbf{B}$ and $\mathbf{C}$ can be defined (Scheme 2).
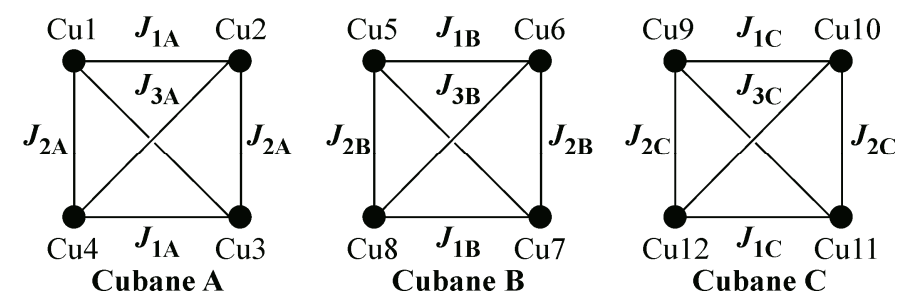

Scheme 2. Magnetic coupling scheme of the $\mathrm{Cu}^{2+}$ ions in complex $\mathbf{1}$

Under this approach the magnetic properties of 1 were analyzed by means of the following nine- $J$ isotropic Hamiltonian Eq. (1):

$$
\begin{gathered}
H=J_{1 \mathrm{~A}}\left(S_{1} S_{2}+S_{3} S_{4}\right)-J_{2 \mathrm{~A}}\left(S_{1} S_{4}+S_{2} S_{3}\right)-J_{3 \mathrm{~A}}\left(S_{1} S_{3}+S_{2} S_{4}\right)-J_{1 \mathrm{~B}}\left(S_{5} S_{6}+S_{7} S_{8}\right)- \\
-J_{2 \mathrm{~B}}\left(S_{5} S_{8}+S_{6} S_{7}\right)-J_{3 \mathrm{~B}}\left(S_{5} S_{7}+S_{6} S_{8}\right)-J_{1 \mathrm{C}}\left(S_{9} S_{10}+S_{11} S_{12}\right)- \\
-J_{2 \mathrm{C}}\left(S_{9} S_{12}+S_{10} S_{11}\right)-J_{3 \mathrm{C}}\left(S_{9} S_{11}+S_{10} S_{12}\right) .
\end{gathered}
$$

The results of the fit, in this case proved unsatisfactory. The least squares fitting did not converge and theoretical results have not been reliable. It becomes necessary to put some constraints on the exchange coupling constants in order to get a plausible result. To avoid overparametrization, we have assumed that the exchange coupling constants between the copper(II) ions are equivalent and described by $J=J_{1 \mathrm{~A}}=J_{2 \mathrm{~A}}=J_{3 \mathrm{~A}}=J_{1 \mathrm{~B}}=J_{2 \mathrm{~B}}=J_{3 \mathrm{~B}}=J_{1 \mathrm{C}}=J_{2 \mathrm{C}}=J_{3 \mathrm{C}}$ (Scheme 2). In this case, the experimental magnetic susceptibility data for 1 were analyzed by using the following isotropic Hamiltonian Eq. (2):

$$
H=-J\left(S_{1} S_{2}+S_{2} S_{3}+S_{3} S_{4}+S_{1} S_{4}\right) .
$$

The temperature dependence of the magnetic susceptibility is given by the Eq. (3):

$$
\chi_{m}=\frac{2 N g^{2} \mu_{\mathrm{B}}^{2}}{k T}\left[\frac{2 e^{J / k T}+e^{J / k T}+5 e^{3 J / k T}}{2+6 e^{J / k T}+3 e^{J / k T}+5 e^{3 J / k T}}\right](1-\rho)+\frac{N g^{2} \mu_{\mathrm{B}}^{2}}{k T} \rho+N_{\alpha},
$$


where $N, g, \mu_{\mathrm{B}}, k, T$ have their usual meanings, $\rho$ is the fraction of paramagnetic impurity and $N_{\alpha}$ is the temperature independent paramagnetism. The best-fit parameters obtained by least squares fit through Eq. (3) are as follows: $J=-108.46 \mathrm{~cm}^{-1}, g=2.3, \rho=0.068, N_{\alpha}=0.012$ with $R=0.9951$ ( $R$ is the agreement factor defined as $\left.R=\sum\left(\chi_{\text {obsd }}-\chi_{\text {calcd }}\right)^{2} / \sum\left(\chi_{\text {obsd }}\right)^{2}\right)$. These results indicates the presence of antiferromagnetic exchange interaction between $\mathrm{Cu}^{2+}$ ions in $\mathbf{1}$. The $g$ values are higher than expected; they may be contaminated by some correlation in the evaluation of $J$. However, in general, the result of the magnetic analysis is in agreement with recent studies on this class of compounds [23-25].

\section{CONCLUSIONS}

We presented the synthesis, crystal structure analysis, and magnetic properties of a tetranuclear copper(II) complex with $\mathrm{Cu}_{4} \mathrm{O}_{4}$ core, representing the $4+2$ cubane class with three independent distorted open-cubanes. Three open $\mathrm{Cu}_{4} \mathrm{O}_{4}$ cubanes have significant differences in the $\mathrm{Cu} \cdots \mathrm{Cu}$ and the $\mathrm{Cu}-\mathrm{O}$ distances and the $\mathrm{Cu}-\mathrm{O}-\mathrm{Cu}$ angles. The magnetic susceptibility measurements $(2-300 \mathrm{~K})$ demonstrate antiferromagnetic interactions.

Crystallographic data for the structure reported in this paper have been deposited with the Cambridge Crystallographic Data Centre (The Director, CCDC, 12 Union Road, Cambridge, CB2 1EZ, UK; e-mail: deposit@ccdc.cam.uk; www: http://www.ccdc.cam.ac.uk; fax: +44 1223 336033) and are available free of charge on request, quoting the Deposition No. CCDC 826610.

The authors are grateful to TUBITAK (Grants No.: TBAG-108T431) and the Research Funds of Balikesir University (BAP-2012/122) for the financial support. Dr. Kara also thanks the Nato-B1TUBITAK and the Royal Society short visit fellowship for financial support and Prof. Guy Orpen (School of Chemistry, University of Bristol, UK) for his hospitality. The authors are also very grateful to Dr. Mairi F. Haddow (The School of Chemistry, University of Bristol) for the X-ray measurement, and Dr. Lorenzo Sorace and Dr. Andrea Caneschi (Department of Chemistry, University of Florence) for the SQUID measurements.

\section{REFERENCES}

1. Kahn O. Molecular Magnetism. - Weinheim: VCH, 1993.

2. Kaim W., Schwerderski B. Bioinorganic Chemistry: Inorganic Elements in the Chemistry of Life. - Chichester: John Wiley, 1994.

3. Feng P.L., Beedle C.C., Koo C., Wernsdorfer W., Nakano M., Hill S., Hendrickson D.N. // Inorg. Chem. -2008. - 47. - P. 3188.

4. Zeng M.-H., Yao M.-X., Liang H., Zhang W.-X., Chen X.-M. // Angew. Chem., Int. Ed. - 2007. - 46. - P. 1832.

5. Petit S., Neugebauer P., Pilet G., Chastanet G., Barra A.-L., Antunes A.B., Wernsdorfer W., Luneau D. // Inorg. Chem. - 2012. - 51. - P. 6645.

6. Vaddypally S., Kondaveeti S.K., Zdilla M.J.// Inorg. Chem. - 2012. - 51. - P. 3950.

7. Sharp C.R., Duncan J.S., Lee S.C. // Inorg. Chem. - 2010. - 49. - P. 6697.

8. Ruben M., Rojo J., Romero-Salguero F.J., Uppadine L.H., Lehn J.-M. // Angew. Chem., Int. Ed. - 2004. - 43. - P. 3644.

9. Cozzi P.G. // Chem. Soc. Rev. - 2004. - 33. - P. 410.

10. Lippard S.J., Berg J.M. // Principles of Bioinorganic Chemistry. - Mill Valley, CA: University Science Books, 1994.

11. Miller S., Drillon M. (Eds.). Magnetism, molecules to Materials. Vols. 1-5. - Weinheim: Wiley-VCH, 2001-2005.

12. Naiya S., Sarkar B., Song Y., Ianelli S., Drew M.G.B., Ghosh A. // Inorg. Chim. Acta. - 2010. - 363. - P. 2488.

13. Puterova-Tokarova Z., Mrazova V., Kozisek J., Valentova J., Vranovicova B., Boca R. // Polyhedron. - 2014. - 70. - P. 52.

14. Tercero J., Ruiz E., Alvarez S., Rodríguez-Fortea A., Alemany P. // J. Mater. Chem. - 2006. - 16. - P. 2729.

15. Gungor E., Kara H. // Inorg. Chim. Acta. - 2012. - 384. - P. 137.

16. Haddow M.F., Kara H., Owen G. R. // Inorg. Chim. Acta. - 2009. - 362. - P. 3502.

17. Elerman Y., Kara H., Elmali A. // Z. Naturforsch. - 2003. - 58a. - P. 363.

18. Elerman Y., Kara H., Elmali A. // Z. Naturforsch. - 2001. - 56b. - P. 1129.

19. Kara H., Elerman Y., Prout K. // Z. Naturforsch. - 2001. - 56b. - P. 719. 
20. Kara H., Elerman Y., Prout K. // Z. Naturforsch. - 2000. - 55b. - P. 796.

21. Song Y., Massera C., Roubeau O., Gamez P., Lanfredi A.M.M., Reedijk J. // Inorg. Chem. - 2004. - 43. - P. 6842.

22. Gungor E., Kara H., Colacio E., Mota A.J. // Eur. J. Inorg. Chem. - 2014. - 9. - P. 1552.

23. Chakraborty J., Thakurta S., Pilet G., Luneau D., Mitra S. // Polyhedron. - 2009. - 28. - P. 819.

24. Liu M.L., Dou J.M., Cui J.Z., Li D.C., Wang D.Q. // J. Mol. Struct. - 2012. - 1011. - P. 140.

25. Lu J.W., Huang Y.H., Lo S., Wei H.H. // Inorg. Chem. Commun. - 2007. - 10. - P. 1210.

26. Koikawa M., Yamashita H., Tokii T. // Inorg. Chim. Acta. - 2004. - 357. - P. 2635.

27. Gungor E., Celen S., Azaz D., Kara H. // Spectrochim. Acta, Part A. - 2012. - 94. - P. 216.

28. Bruker-AXS SAINT V7.60A.

29. Sheldrick G.M. SADABS V2008/1. - Germany: University of Göttingen.

30. Sheldrick G.M. SHELXTL. Version 5.1. Program for the Solution and Refinement of Crystal Structures. - Madison, WI: Bruker AXS, 1999.

31. Spek A.L. // J. Appl. Crystallogr. - 2003. - 36. - P. 7.

32. Hathaway B.J., Wilkinson G., Gillard R.D., McCleverty J.A. (Eds.). Comprehensive coordination chemistry. - Vol. 5. - Oxford, UK: Pergamon Press, 1987.

33. Addison A.W., Rao T.N., Reedijk J., Van Rijn J., Verschoor G.C. // J. Chem. Soc., Dalton Trans. - 1984. - P. 1349.

34. You Z.L., Zhu H.-L. // Z. Anorg. Allg. Chem. - 2004. - 630. - P. 2754.

35. Thakurta S., Chakraborty J., Rosair G., Butcher R.J., Mitra S. // Inorg. Chim. Acta. - 2009. - 362. - P. 2828. 